\title{
Hvordan indsætter forfatteren litteraturlister i OJS?
}

Vejledning i hvordan forfatteren indskriver sin litteraturliste, så den indgår som del af metadata.

Når forfatteren indleverer sit manuskript online, skal han på tredje side i upload-processen (Trin 3) indføre diverse metadata, som forfatternavn, titel, resumé mm. Nederst på denne side findes et felt (Referencer), hvor en eventuel litteraturliste skal indskrives, hvis tidsskriftet ønsker at tildele DOI til artiklerne. Såfremt en reference har et DOI, skal dette ligeledes fremgå her.

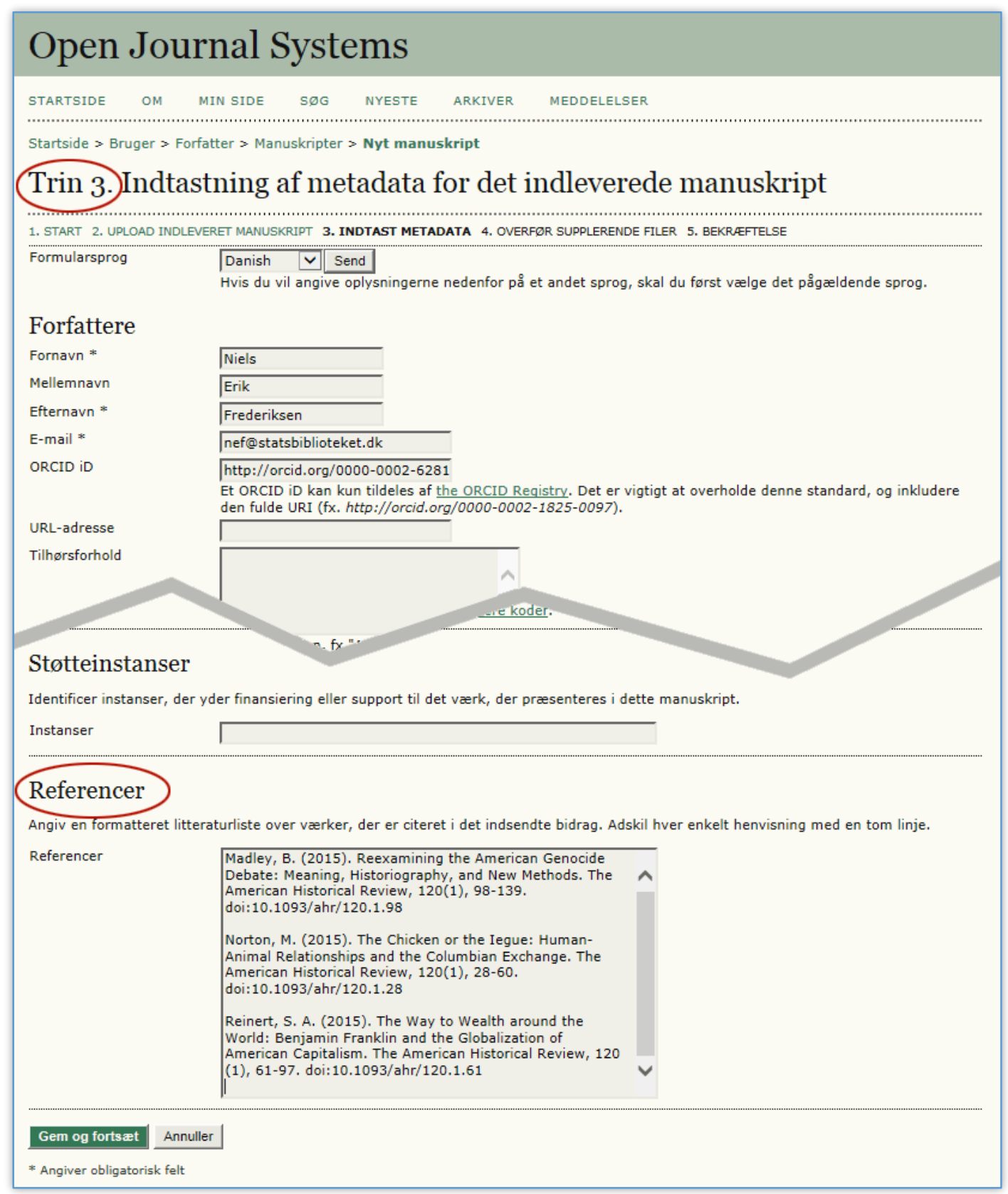

Niels Erik Frederiksen og Jesper Boserup Thestrup, marts 2015 